\title{
The Development of English Grammar Book Through Direct Method: Research and Development Study at Mambaus Sholihin English
} Course

\section{Alsuna: Journal of Arabic and English Language}

\section{Imam Nur Aziz}

Institut Keislaman Abdullah Faqih ⓘmamnuraziz@gmail.com

\section{Keywords:}

Instructional Material

English Book

Direct Method

Mambaus Sholihin English Course

Article Information:

Submitted: April 06, 2020

Accepted: April 20, 2020

Approved: May 18, 2020

\section{Introduction}

\section{Abstract}

Purpose - This research aims to understand the development of English book material for Grammar at Mambaus Sholihin English Course (MEC) Gresik.

Design/methodology/approach - This research applied the Educational Research and Development (RnD) to develop the contents. This research method deals with the researcher's purpose wants to be aimed by need analysis, drafting the document, organizing material, review, expert validation, revision I, try out, and correction II.

Findings - This product has been suitable for the students' needs to help them in learning grammar to be easier understood and practiced. The result shows that book is appropriated with the purposed to help them who need this research and development in relaxed and fun learning of grammar notification. Also, this book is completed with direct method although it is used in speaking skill more, it is also suitable for grammar in learning and teaching.

Originality/value - It is important for a teacher or tutor to innovate in designing a teaching book that suits the needs of students. Especially for students who do not have a study handbook.

Paper type - Research paper

It is not an anxiety word to say that language is an arbitrary system. It is the system of communication in speech and writing used by people of a particular country or the use by the human of a network of sounds and words to communicate (Aziz and Dewi 2019a). The arbitrariness describes the aspect of the relationship between words and objects (Yule 2016). Communication itself means activity or methods of sending information, idea, and feeling or another message (Oxford 2013). Krashen and Terrel said that communication is the primary function of language and a vehicle for communicating meaning and messages (Krashen 1982). So, it concludes that language is the primary source of communication. As an addition, Zeeshan Naved says that it is something to make us human and separate us from animals (Naved 2016). 
Without language, it will be so difficult to assimilate the ideas appear in others mind also give the significant impact of our life.

One of the famous and familiar languages is English either as a second language or foreign language. The word uses in any tools of communication like trade language, international language, auxiliary language, and contact language (Wardhaugh 2006; Aziz and Dewi 2019a). So that English is not only learned by England but also most of the people in the world. Moreover, English is an international common tongue. The majority can see it of websites and press that created in English, however the business area. English takes an essential part in the education field substantially, too (Naved 2016).

Language exists in a context, and the meaning and purposes for which word determine how communication realize at the levels of text and grammar (Garrett 2003). Widodo state further to furnish the basis for a set of language skills: listening, speaking, reading, and writing (Widodo 2006). In language learning grammar plays a crucial part in grasping and expressing spoken language (e.g. expressions) since learning the syntax of a word is considered necessary to acquire the capability of producing grammatically acceptable utterances in the literature (Aziz and Dewi 2019b). In reading, grammar enables learners to be comprehended sentence interrelationship in a paragraph, a passage, and a text. In the context of writing, the syntax allows the learners to place their ideas into intelligible sentences so that they'll successfully communicate in an exceedingly written form. Finally, in the case of vocabulary, grammar provides a pathway to learners how some lexical items should be combined into a proper sentence so that meaningful and communicative statements or expressions can form. On another side, Doff adds that by learning grammar, students can express meanings in the form of phrases, clauses, and sentences. Long and Richards also said that it could not ignore that grammar plays a central role within the four language skills and vocabulary to determine communicative tasks (Widodo 2006).

Grammar becomes the main point of the essential components in mastering those skills. A grammar that it is a systematic way of approaching the study of linguistic facts while prescriptive grammar could be a means to take care of linguistic excellence. Prescriptive grammar tries to preserve what's assumed to be the quality language by telling people what rules they must know and the way they must speak in write (Weaver 1996). Teaching grammar to ESL and EFL learners is aimed at helping them to internalize the rules and patterns that can apply in language use (Weaver 1996). 
In the learners' case, grammatical rules enable them to grasp and apply how the sentence patterns should arrange together. The grammar teaching should also ultimately center attention on the way grammatical items or sentence patterns use correctly. Learning grammar should encompass language structure or sentence patterns, meaning, and use. Many teachers think that teaching grammar is not favorable to learners since learners only learn the way of a constructed language. Very often, after the teachers give grammatical rules, the learners work well in such cases. However, when they speak or write, learners make grammatical errors or even unnecessary. To help the learners to apply grammatical rules into communicative tasks is incredibly challenging. Therefore, teachers could benefit from learning some alternative teaching approaches for teaching grammar; it can incorporate structure into other language skills in some goal of language learning (Widodo 2006). while the teacher should introduce the use of the spoken word systematically-proceeding gradually according to the complexity of the language structure presented (Capperucci 2017). In the case of teaching grammar to EFL learners, a teacher may feel frustrated when the teacher teaches the learners grammatical items separately. Students may become good at grammar; however, when told to write and speak, they often make grammatical mistakes. This case is very challenging to be solved (Widodo 2006). That's true that after the students having the material, they don't understand, because they are still confused and asking each other.

Transferring another language to ours needs to be attention to get a master's in language skills. One of them that familiar and famous is the Direct Method. According to Larsen-Freeman on Cagry Tugul, it has been popular since it enables students to communicate in their foreign language. This method by focusing on everyday language. The objective of this method is to associate meaning and the target language directly through the use of reality, picture, or pantomime (Mart 2013).

In Indonesia, any institution learns English from all of the age stages. No leaving this Salafi-modern Pesantren (Aziz and Dewi 2019a), Mambaus Sholihin, with the basic is Pondok Bahasa. This pesantren uses two languages; it is English and Arabic languages in daily activity. Many activities do to enrich English students' competencies and skills whether speaking, listening, reading, writing, and other competencies support those skills like grammar, pronunciation, and vocabulary such as speech training, conversation, drill, and course that this course under Mambaus Sholihin English Course (MEC). 
Teaching and learning in MEC point out at one activity that supports the students in language backing up, as mentioned above. But in the long run, this activity is not as it is. It is just going on but has no quality. Finally, it gives a significant impact on the students. What they should catch was just precisely on nothing. Poorly, there are no media that hands undoubtedly. The students have no guiding book on their hands.

Moreover, the materials do not offer the tutors and students non-mastering of several elements to the students which caused the reviewing material, no-sequencing material, just a little piece- little piece cause students to feel difficult to accept the content. Also, the way that tutors do seems boring, feels monotonous, no interesting and, etc. For those reasons, the students feel difficulty in the learning process and get no comprehension. At least, if there was a book, students can learn by themselves either by reading or doing tasks in that book to fulfill their needs and didn't leave off the materials. It helps the students in many aspects of the language competencies as mentioned above, still moreover grammar. Grammar becomes something difficult to learn by the students at the $5^{\text {th }}$ level of MEC. Such as in the understanding of tenses, several parts of speech they feel confused, etc.

\section{Methodology}

This research applied the Educational Research and Development (RnD) to develop the materials. This research method deals with the researcher's purpose wants to be aimed. The procedure of this research applied Adnan Latief's adapted model of educational research and development (Latief 2010)as the following steps below:

Need analysis, Need analysis will be done to find the students' needs out through data analysis techniques to collect information about it. Then, to realize it, the researcher gave the questionnaires in the multiple-choice form with the answer is more than one for about twenty items based on Hutchinson and waters (Tom and Waters 1987) which consist of two parts: target situation needs and learning needs considering some aspects such necessities, lacks, wants, goal, learning material content and topic, English proficiency and weakness in learning English. And for the teacher is ten items. The goal is to conduct the students' needs; then the result will be used in writing course grid and organizing materials until the product is ready to use and publish.

Drafting document, In this section, the data were drafted as the result of the questionnaire and interview. In short, it is conducted as they solve. The data that had been 
gotten are drafted and implemented in the course grid form also out-line of the materials that appropriate with students' needs of the $5^{\text {th }}$ level on MEC.

Organizing material, This part did after the document was drafted, which the researcher compiled the material from several references to get the material that deals with the students' needs. After analyzing the students' needs and drafting the document, material organizing write and conduct considering some aspects, such as the language use, sequencing material, etc. to easy for students to understand, interest them, and no-boring one. This step considers the vision and mission of MEC in the $5^{\text {th }}$ level, which uses the direct method that may help students in learning and teaching grammar process to be practiced well based on the topics they need.

Review, The review holds to examine carefully by the researcher herself of both contents and to set beforehand it to the experts. The goal of this step is to check over and get the revision. On the other hand, this step will do to minimalize the false.

Expert validation, By this step, the product validated by two experts who are enough knowledge about the field, the first is on material who will give the correctness about content, language structuring or language use, was it easy to be understood or wasn't, etc. And the second is on book design who will give the revision either cover, setting or layout, etc. The goal is to get the input by the experts of the product to be evaluated and repaired by the researcher either from weakness, lacks, or addition.

Revision 1, After getting the directions from the experts, the researcher revised the product as it should be to be appropriated with the student's need for the $5^{\text {th }}$ level of MEC.

Try out, After the product is made by the researcher, getting validation and revision from the experts, the product was tried-out to the students by giving a questionnaire to deal about the book and the student's need of $5^{\text {th }}$ level at MEC in grammar competence also the language used in this book can be enough understood for students and unusual for them. This section is the important one because this is trying out to determine the properness in the use of the product.

Revision 2, The next revision did after doing the tryout of the product based on several questionnaires given to the students by considering some aspects. This step is for completing and ensuring that the product is ready.

Publishing, After doing the steps mentioned above, the product was ready to publish and can be used in the teaching and learning process. 
The subject of the development, This research took the students of the $5^{\text {th }}$ level of Mambaus Sholihin English Course as the subject of the study that refers to the $2^{\text {nd }}$ grade of MA Mambaus Sholihin Gresik students. This level consists of eight classes from A until H., But mainly, the researcher only focused on one course (B) of them with the number of students is 28 persons.

Data collection method, As the resources of the data, this research used questionnaires and interviews. The questionnaire was given to the students twice; the first step conducted need analysis, and the second step undertaken the evaluation of the product. For the interview, it was given to the teacher of the English course. 1. Interview: it used to gather the information directly from who are in related sources., 2.Questionnaire: this technique is used to find out the need of students consists of some questions given to the students. After collecting the data, they were analyzed with descriptive qualitative.

\section{State of The Arts and Distinguish}

Richards and Rodgers say that view materials as a way of quality influencing classroom interaction and language use (Richards and Rodgers 2014). Also, Tomlinson defines elements as any tools in the forms both audio-video, and printed-no printed used things to facilitate the learning of the language, not only restricted to coursebooks (Tomlinson 2003). For example CD ROMs, dictionaries grammar books, workbooks, photocopied exercises, etc.

Through the background that has mentioned, the researcher states that the research problem is how to develop an English grammar book appropriated with the $5^{\text {th }}$ level students of Mamba's Sholihin English Course (MEC) ?. The objective is to develop an English grammar book based on the direct method for 5th level students of Mambaus Sholihin English Course (MEC). This book conducted to make the students to be more comfortable in understanding grammar material and to help them in the teaching and learning process until the goal of it is as expected.

\section{Result and Discussion}

The researcher started identifying students' problems in the learning process by giving questionnaires for obtaining information to the $5^{\text {th }}$ level of MEC students which use $2^{\text {nd }} B$ class that consists of 28 students conducted on March $15^{\text {th }}, 2020$. The questionnaire consisted of twenty questions related to their problems in learning grammar. The first until ninth questions 
were the questions for obtaining information. The tenth until the twentieth questions were the questions for getting need analysis. Through their answer in the questionnaire, the question number one until nine, it was found data as served below:

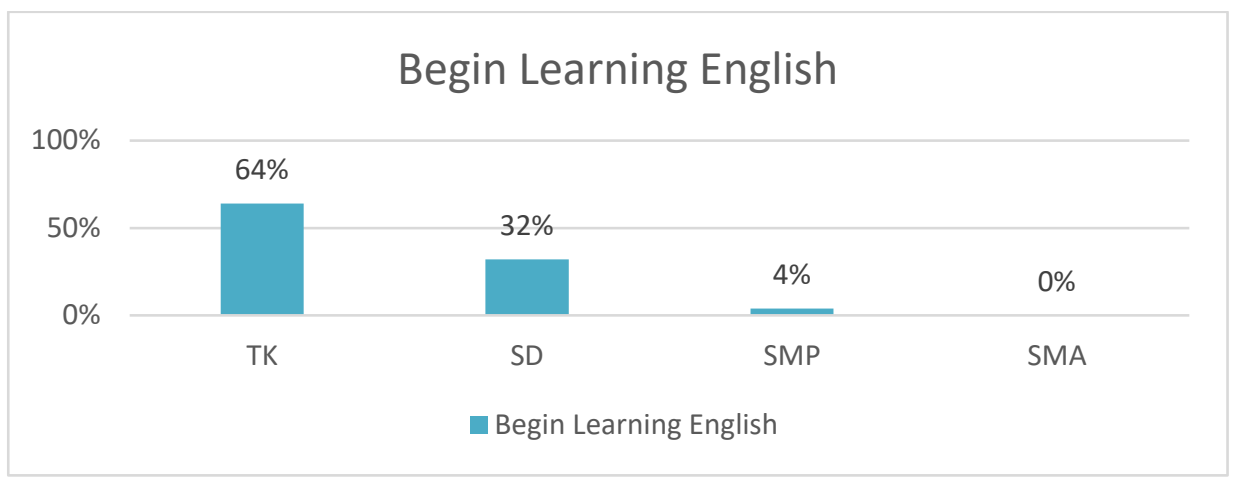

Figure 1: Begin learning English

It showed that most of the $5^{\text {th }}$ level of MEC students started for learning English since they are in kinder garden school (TK). The researcher could conclude that they were having enough knowledge in English because they learn English in kinder garden school (TK).

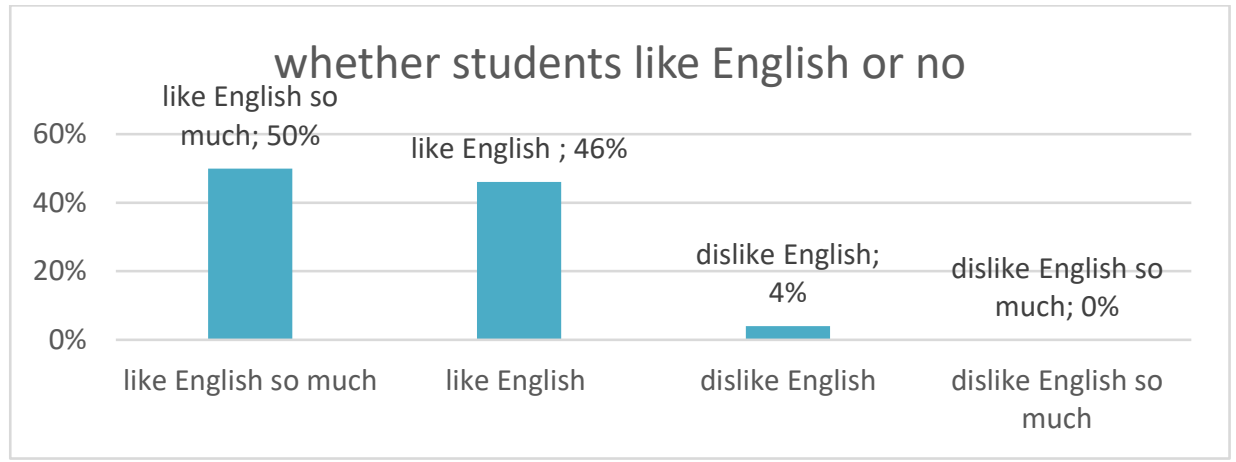

Figure 2: Whether students like English or no

The researcher found that most of the $5^{\text {th }}$ level of MEC students said that they liked English so much. It was concluded that they have an excellent interest in English.

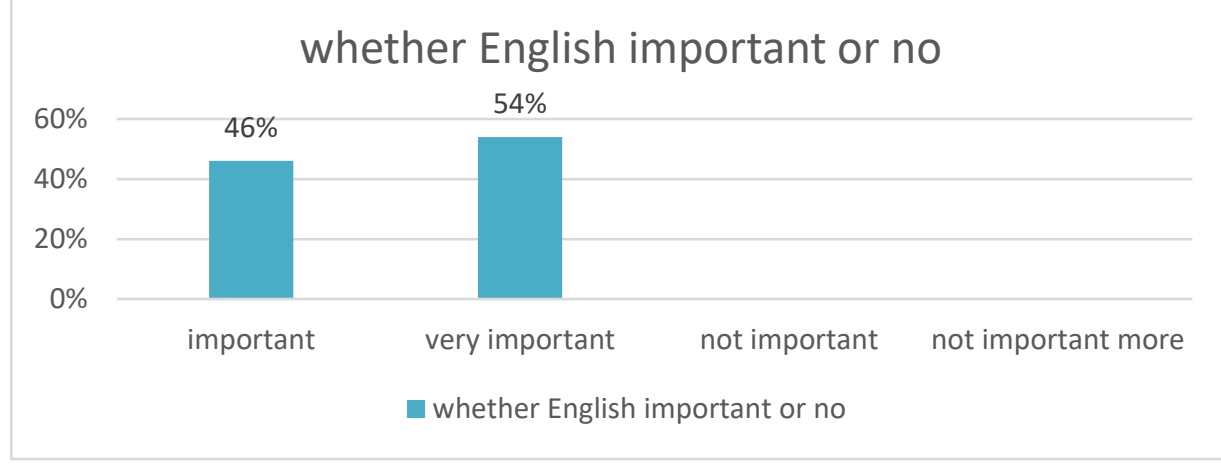

Figure 3: Whether English important or no

It showed that most of the $5^{\text {th }}$ level of MEC students noted that English was necessary for them. 


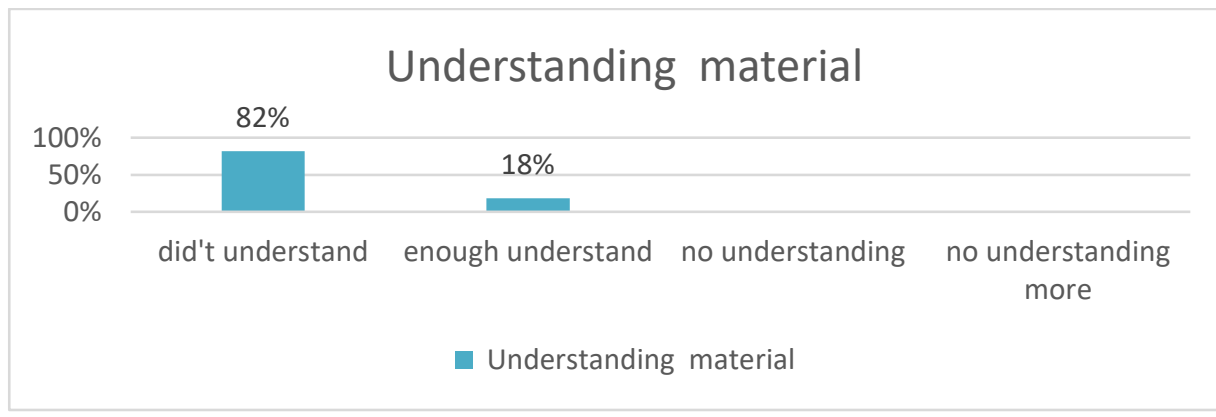

Figure 4: Understanding material

It concludes that most of the $5^{\text {th }}$ level of MEC students said that they did not understand the content given by their tutors.

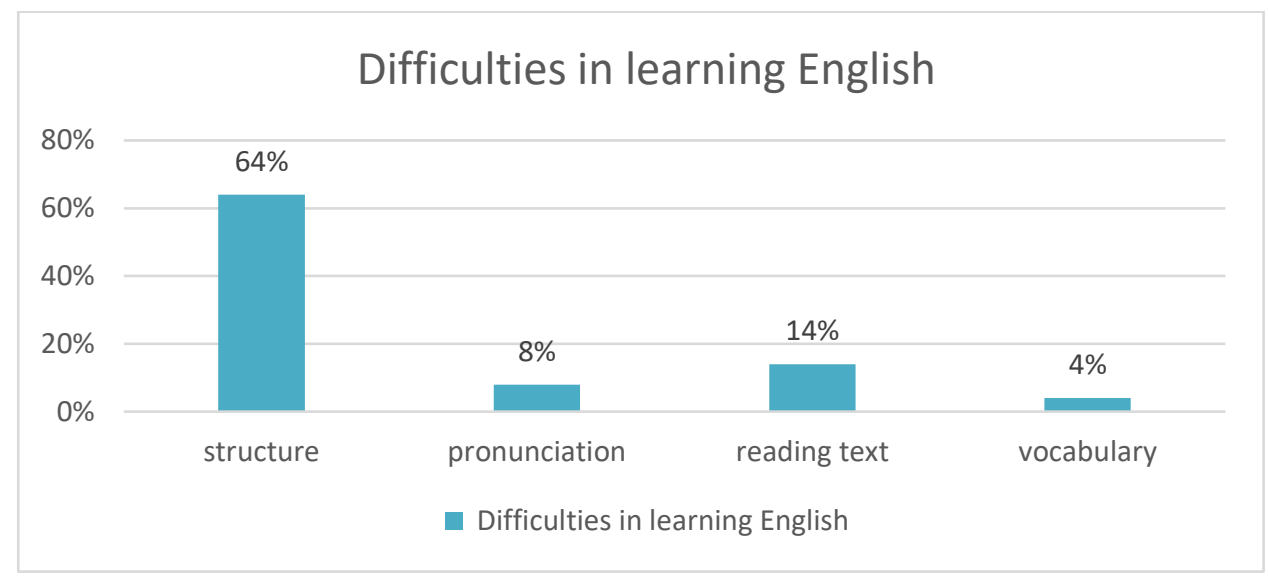

Figure 5: Difficulties in learning English

It indicated that most of the $5^{\text {th }}$ level of MEC students said that they got problems in learning structure.

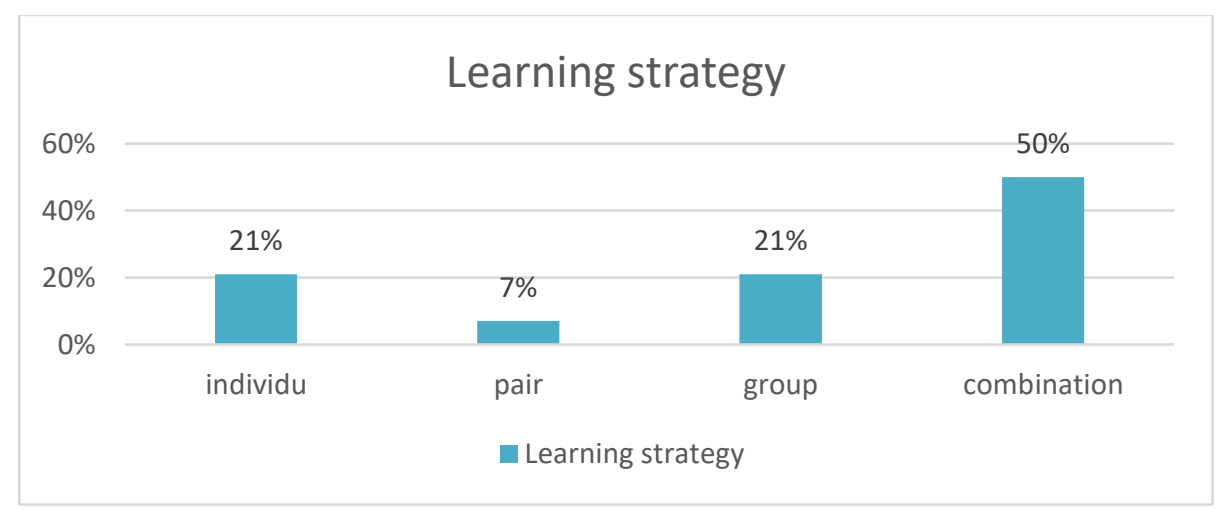

Figure 6: Learning strategy

It meant that most of the $5^{\text {th }}$ level of MEC students said that they need anyways in learning English to get variation and make the students enjoy while learning process 


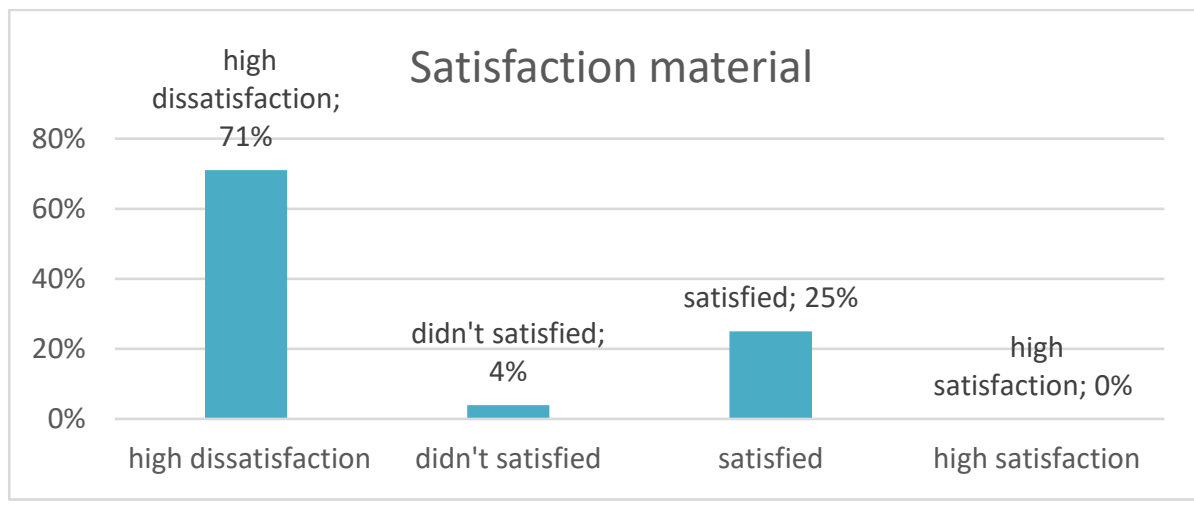

Figure 7: Satisfaction material

It showed that most of the $5^{\text {th }}$ level of MEC students said that they feel enough dissatisfaction with the content has been given.

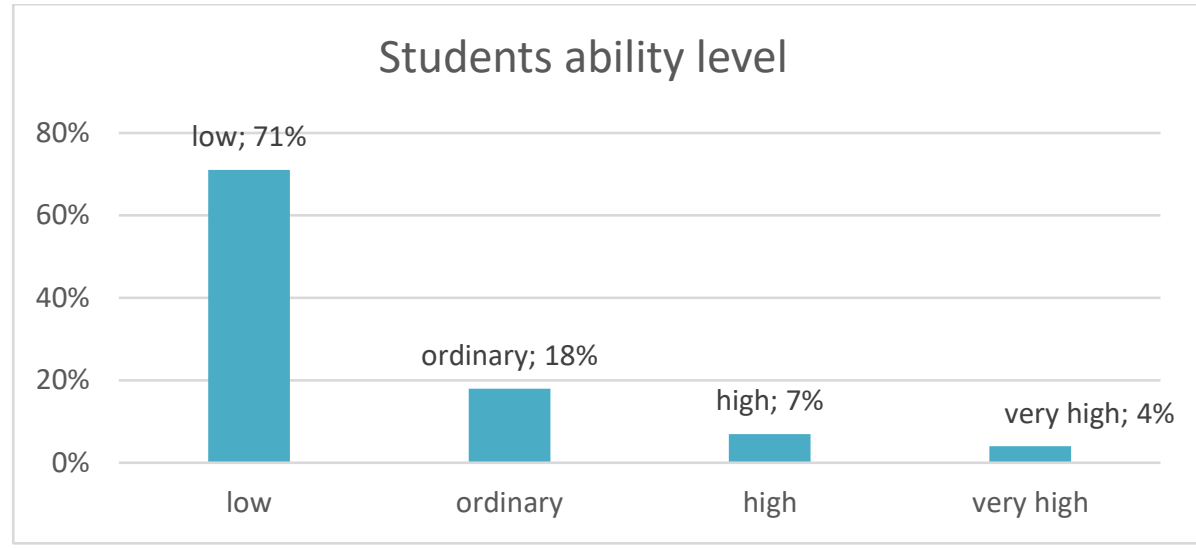

Figure 8: Students ability level

So, it showed that most of the $5^{\text {th }}$ level of MEC students said that their mastering of English is low.

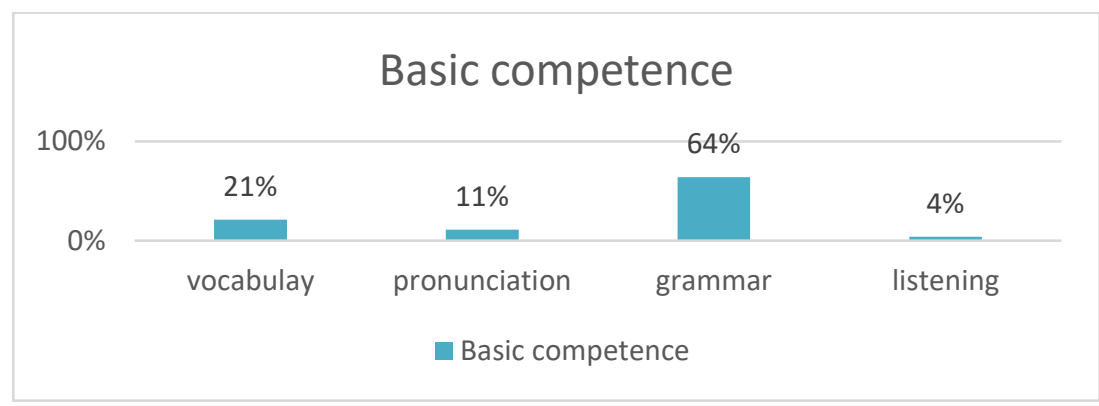

Figure 9: Basic competence

Thus, the conclusion is the most of the $5^{\text {th }}$ level of MEC students said that stated that English proficiency should be determined is grammar. 


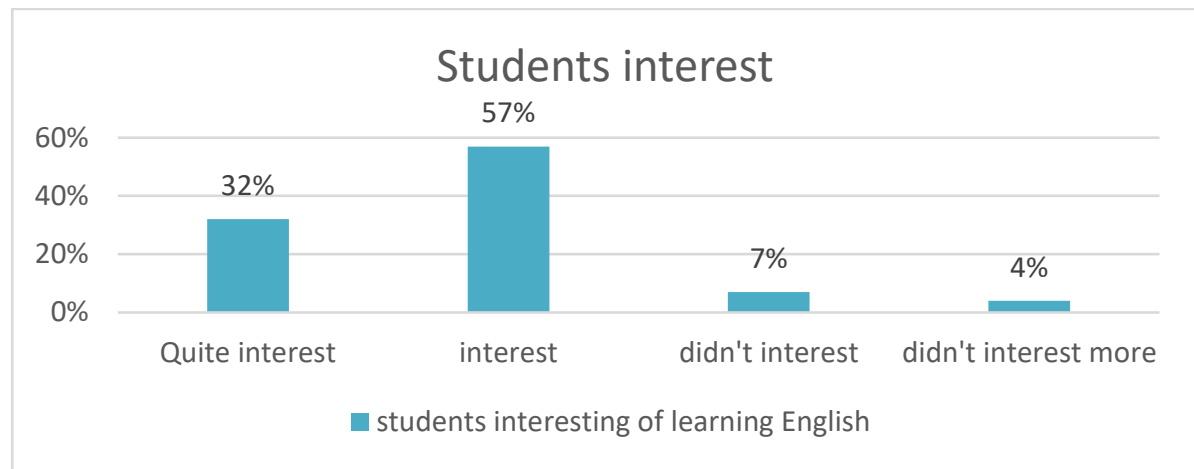

Figure 10: Basic competence

From this, the conclusion is the most of $5^{\text {th }}$ level students of MEC have well enjoyable in learning English grammar.

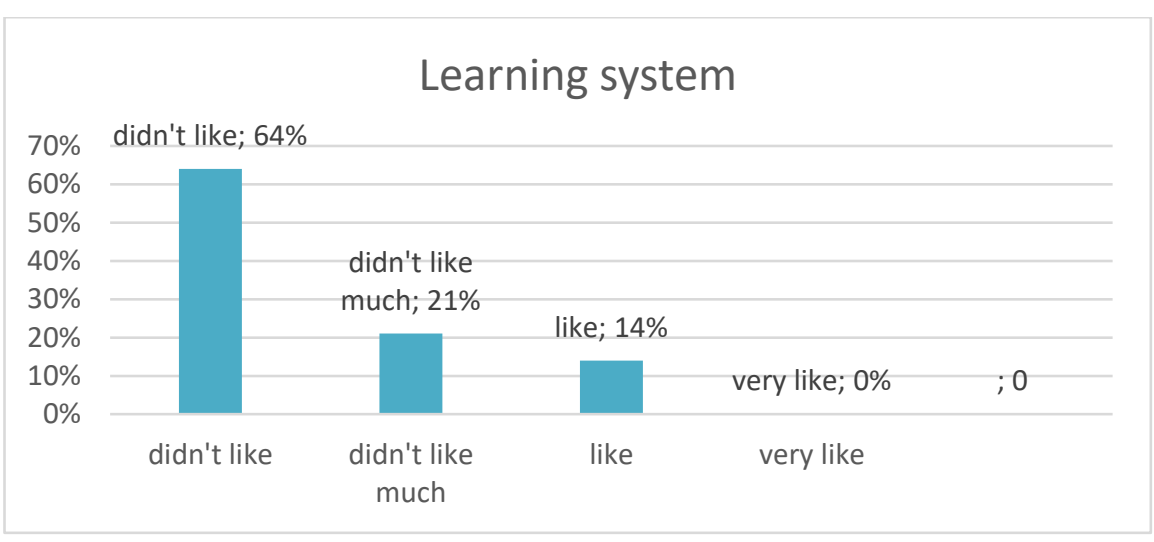

Figure 11: learning system

The most of $5^{\text {th }}$ level students of MEC did not like the method of learning grammar in the class.

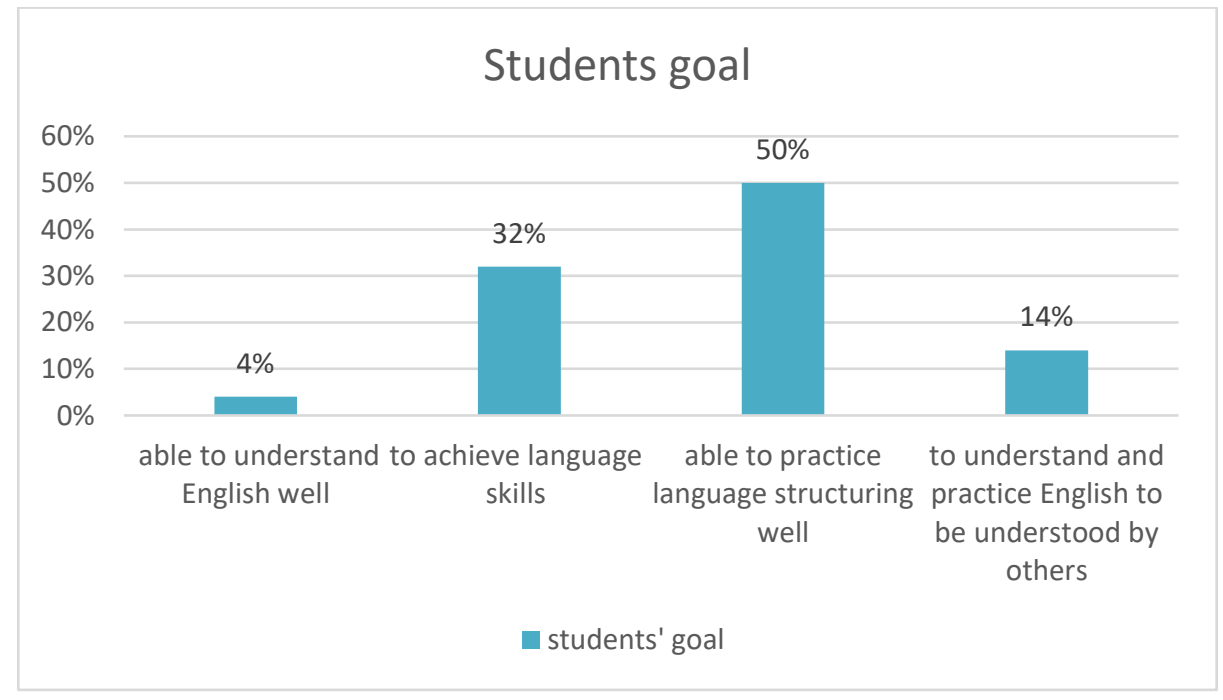

Figure 12: Students goal 
It showed that most of the $5^{\text {th }}$ level students of MEC hoped at their grammar achievement to conduct their various wishes in using English clearly and able to be understood by others.

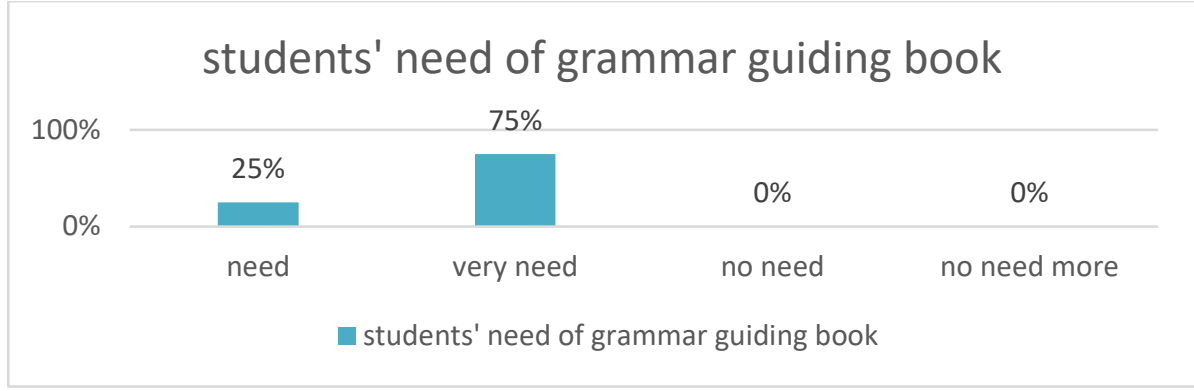

Figure 13: students' need for grammar guiding book

It can be concluded that most of the $5^{\text {th }}$ level students of MEC noted that they need grammar guiding book seriously.

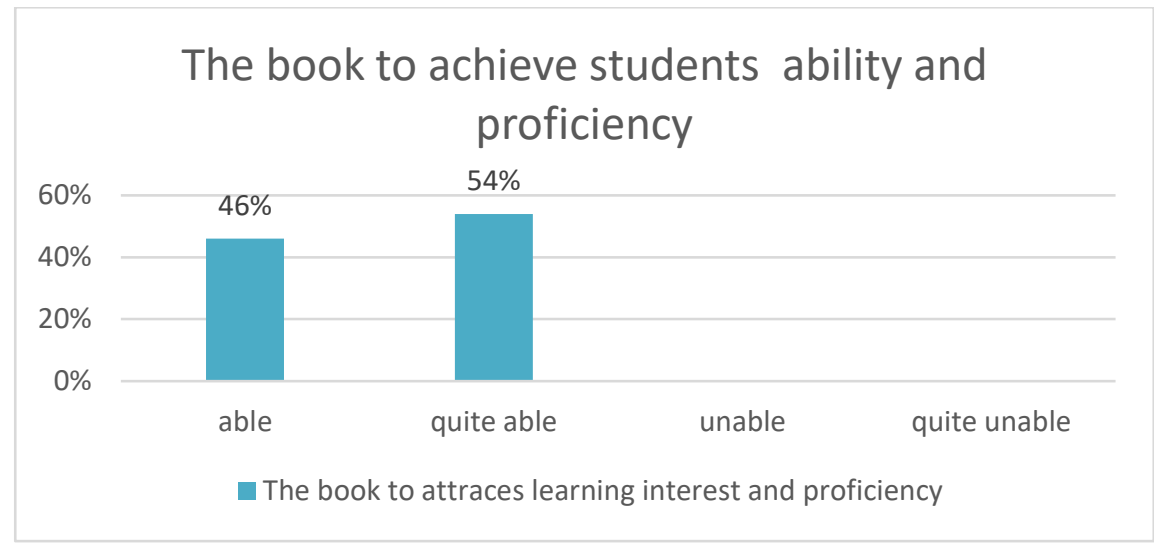

Figure 14: The book to achieve students ability and proficiency

It concludes that most of the $5^{\text {th }}$ level students of MEC said that the book achieves students' proficiency and able to support them in learning grammar highly.

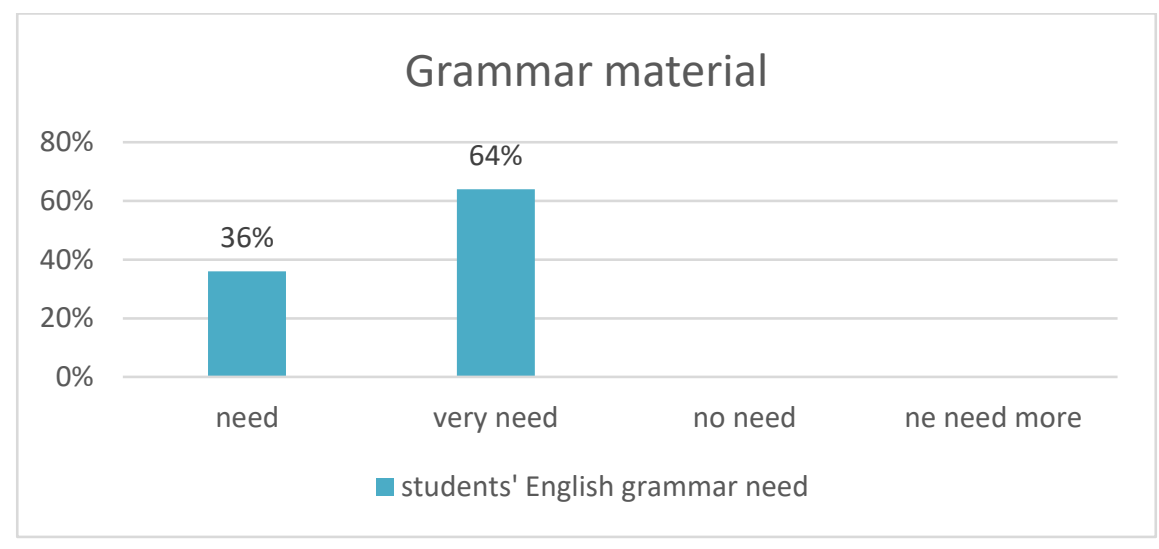

Figure 15: Grammar material 
From 28 students, 10 of them or $36 \%$ of students said that English grammar is the necessity to achieve four skills of English.18 of them or $64 \%$ of students said that e English grammar is very needed to complete four skills of English. So, grammar is essential to achieve four skills of English.

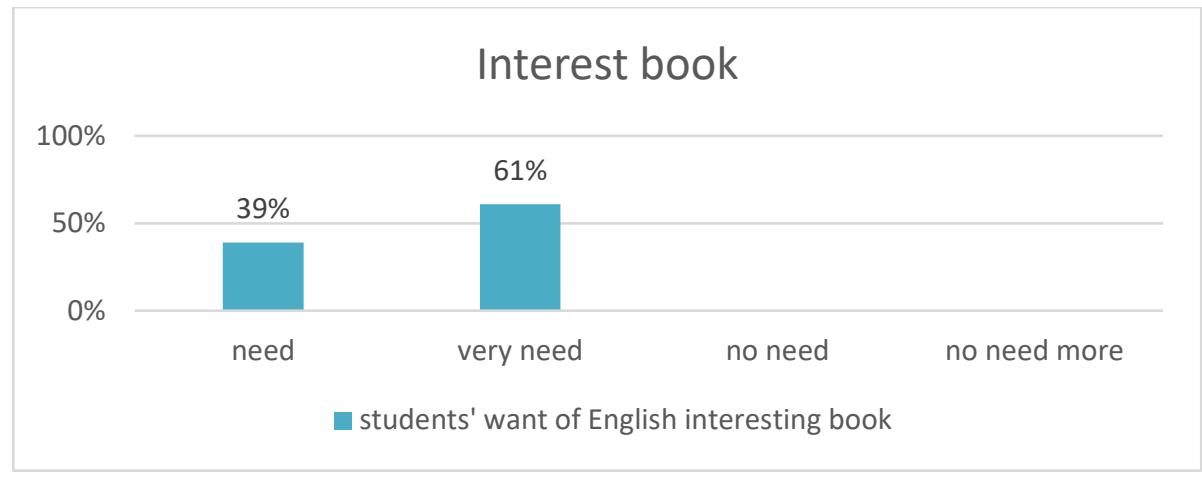

Figure 16: Interest book

The most of $5^{\text {th }}$ level students in MEC are very needed for English interesting book in guiding them to learn.

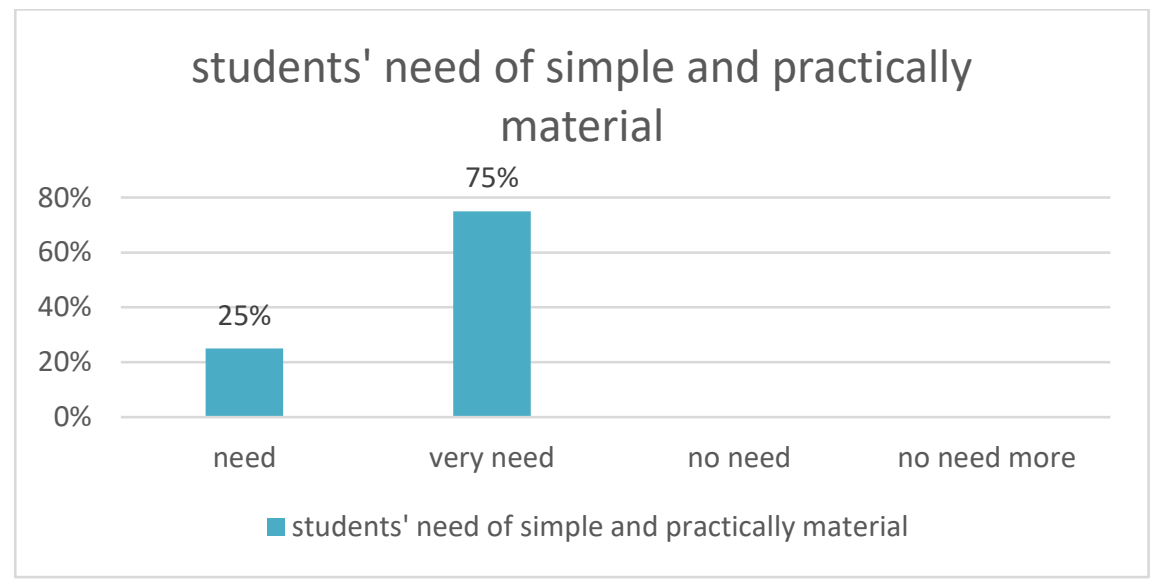

Figure 17: students' need for simple and practically material

It showed that most of the $5^{\text {th }}$ level students in MEC are very needed in English interesting book in conducting them to learn.

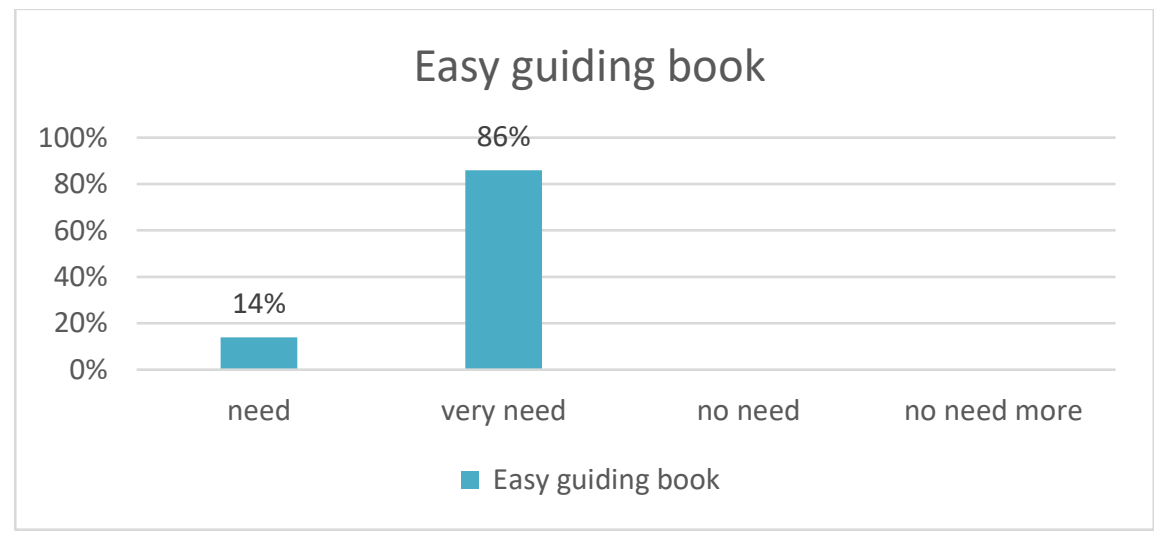

Figure 18: Easy guiding book 
So, most of the $5^{\text {th }}$ level students in MEC need to have an easy book that has brief and natural language to be understood by then while learning.

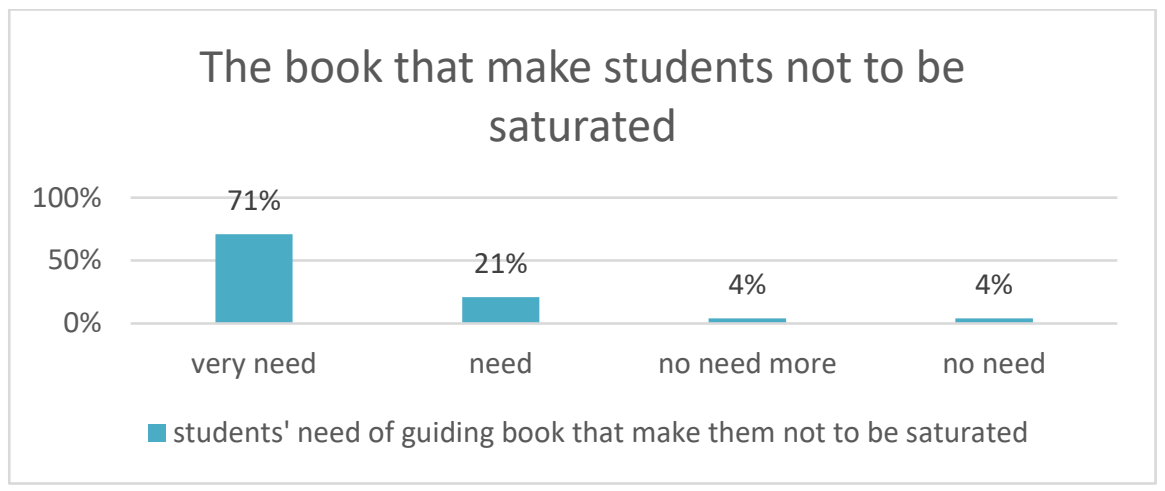

Figure 19: The book that makes students not to be saturated

It can be concluded that most of the $5^{\text {th }}$ level students in MEC are very needed to have a guiding book that makes them not to be saturated.

\section{The importance of illustration, picture and examples in learning English grammar}

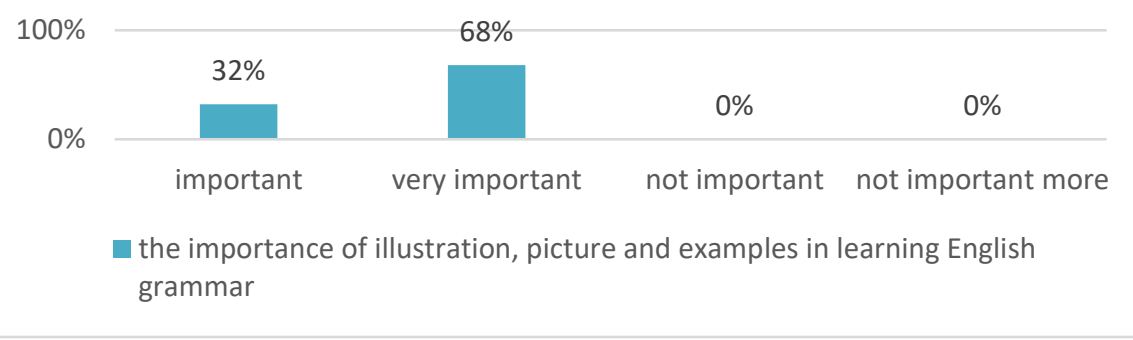

Figure 20: The importance of illustration, picture, and examples in learning English grammar

It showed that most of the $5^{\text {th }}$ level students in MEC are very needed to have a guiding book which has an illustration and picture also examples in learning English grammar.

Based on the result of need analysis, there were some facts from the effect of questionnaires which became the basis for the researcher in making product: 1) Although the students had enough knowledge in English since their child, they still don't understand and can't practice English well. 2) Most students have a good interest in English. They want to know about English anymore. Indeed, the students agreed that English was essential to be learned because different reasons and considerations students have. 3) Many difficulties students found in learning English, some of them have trouble in vocabulary, some of them have a problem with pronunciation, etc. But most of them stated that they complain about how to structure the sentence to be a good sentence in order able to get better communication with others by English. So, from this, the students need the grammar to be learned deeply. 4) Also, the students need a fun way while the process of learning for them to understand and practice 
what they got more comfortable. 5) Also, the students need the media that consist of their need as told above to help them in the learning and teaching process.

Those were facts for the researcher to make the book that was appropriated for the students of the $5^{\text {th }}$ level of MEC that refers to $2^{\text {nd }}$-grade students of MA Mambaus Sholihin students (MEC).

In developing an English grammar book, the researcher needs suggestions and opinions from the English teacher to support the data. So, the researcher uses a structured interview in the process of collecting information from the teacher.

The first question asks about the previous book used by the teacher or tutor in teaching grammar at the $5^{\text {th }}$ level of MEC. The teacher answered that she was just given some piece of paper that consists of several materials that should be learned for preparing before coming into class cause it is available from the language department. Also, she claimed that sometimes she just enter the class without making any lessons to be learned and taught.

From this, it indicated that the material hasn't appropriated with the students, and the students need the material suitable for their needs and level. The second question asks about the strategy used by the teacher or tutor in giving grammar material to the students at the 5th level of MEC. The teacher said that there was no strategy she used while learning and teaching process in the class. The teacher also felt confused about how to catch and handle the level in order not too boring and create an awkward moment. By this, it can be concluded that the students need the strategy whether the learning and teaching process that makes them able to understand the material and practice it in students' daily activities as their obligation in this pesantren. Therefore, teachers and students are the main subjects that must be explored by their needs and interests as the main basis of the development of the teaching materials (Amalia 2018).

The third question asks the teacher or tutor about the difficulties faced while teaching and learning grammar processes at the 5 th level of MEC. By some faced challenges, the teacher answered that the main problem the teacher found is on media. The students didn't read the handbook to hold and guide the students to understand the material. In clear, the critical point was found that the students need the appropriate book based on the level that simple and able to be also practiced able to share the student's mind through exercises and activities. The fourth question asks about the language used by the teacher or tutor in teaching grammar at the $5^{\text {th }}$ level of MEC. The teacher admitted that the teacher uses the English language seldom 
when she explains and gives the material in front of the students. It is caused the teacher felt that only some students understand the content when the teacher explains by English. The teacher forgot that she also has to guide students by making the teacher herself as the model to practice English to be followed by them.

The fifth question asks the teacher or tutor about the grammar materials given to the students whether the content can be understood and practiced by the students or can't at the $5^{\text {th }}$ level of MEC and what material suitable with this level based on the syllabus. The teacher said that many of the students have many troubles in understanding the material moreover practicing and about the grammar materials should be given at this level based on the syllabus are 3 chapters; passive voice, direct-indirect speech, and question tag while the students practice more and combine the materials in $4^{\text {th }}$ level that talk more about tenses and vocabularies. So, the content needs any development and the way to hold the students while teaching and learning. The document was drafted from the result of need analysis to the students and the results of the interview with the subject specialist. The results were served below:

Chapter One: Question Tag

Chapter Two: Passive Voice

Chapter Three: Direct-Indirect Speech.

The material was organized after drafting the document process. The researcher gave priority to the grammar for this book because students very needed in it. There were also some additional vocabularies and activities as an exercise for students relevant to the given material. The researcher reviewed the product aimed to check the design and content of the book before validating it to experts. Grammar material needed to be approved by some experts to get the best quality of the material. The expert validation would give evaluation, suggestions, and comments to the book material. The instruments used to evaluate the documents were the checklist and suggestion form.

on the result of expert validation, the researcher revised the book as follow:

1) The researcher reviewed the book mapping and direction of the book to be specific in syntax to the reader not to get the ambiguity of the rule and route of the book.

2) The researcher also tidied up the type of writing in order not to mess.

The revision from the second expert was served as follow: 
1) The researcher reorganized the material to get a good organization and concept in order able to be understood by the reader.

2) The researcher gave a clear instruction objective.

3) The researcher recovered the materials from being entirely appropriate with the students to need.

The researcher reordered the content of the material more logically and able to relate directly to the objective of the instruction. The researcher continued to the next step, i.e. the try out to measure the effectiveness of the product. It conducted at the $5^{\text {th }}$ level students of Mamba'us Sholihin Female English Course (MEC) Gresik. Based on the result of trying out the product. Based on the outcome of the second questionnaire given to the students, some of them added that the book was clear enough but still needs to be revised in the present the material and some stated that they satisfied and felt enjoy with this book. So, the researcher reviewed the content as the students need to be entirely understood by them.

\section{Conclusion}

English course in Mamba'us Sholihin or we call it MEC divided based on the level of students grade that begins from junior high school until senior high school. In the clear, there were six levels under MEC. Some achievements to develop students' language skills were backed up here. Then this final book of researcher gives the contribution to grammar achievement cause grammar is the one way for structuring the language which dedicated to the $5^{\text {th }}$ level of MEC students.

The problem found gives the reason for the researcher to do the research and development that's there is no guiding book for the students. This book was appropriated with the purposed to help them who need this research and development in natural and fun learning of grammar notification. Also, this book is completed with the direct method. However, it is used in speaking skills more, but it is not denied that it is also suitable for grammar in learning and teaching. So, the students will get a simple way to understand and practice.

This book got the validation from the experts of content and design who have many experiences in those fields. So, the direction and suggestion of them had been made in the revision step. Thus, this book is ready to use in learning. And the chapters are as follow:

1. Chapter 1: Maura dances beautifully, doesn't she? 
a. (Discusses question tag)

2. Chapter 2: I found a beautiful rose

a. (Discusses passive voice)

3. Chapter 3: Helmi said that he loved Anya

a. (Discusses direct-indirect speech)

\section{Implications of Findings}

Repentance for a teacher or non-Native Speaks language learning tutor to innovate in designing the breadth of teaching books. Surely the learning book is required according to students. Especially for students who do not have a handbook learn.

\section{Bibliography}

Amalia, Eka Rizki. 2018. “Developing English Textbook Material for Islamic Primary Education Program: A Participatory Action Research." ALSUNA: JOURNAL OF ARABIC AND ENGLISH LANGUAGE 1 (2): 69-77.

Aziz, Imam Nur, and Yuli Ani Setyo Dewi. 2019a. "The Concept of Language Environment: A Descriptive Study at Madrasah Aliah Keagamaan Gresik." EDUKASI: Jurnal Pendidikan Islam 7 (2): 1-23.

- - . 2019b. "The Implementation of Contextual Teaching and Learning on English Grammar Competence." ALSUNA: JOURNAL OF ARABIC AND ENGLISH LANGUAGE. https://doi.org/10.31538/alsuna.v2i2.392.

Capperucci, Davide. 2017. "English Language Teaching and Learning in Primary School. Theoretical and Methodological Perspectives." Studi Sulla Formazione/Open Journal of Education 20 (2): 203-17.

Garrett, Lisa. 2003. "Teaching Grammar in an English as a Foreign Language (Efl) Context." The Australian Journal of Indigenous Education 31: 35-40.

Krashen, Stephen D. 1982. Principles and Practice in Second Language Acquisition. The Modern Language Journal. Vol. 67. https://doi.org/10.2307/328293.

Latief, Ahmad Adnan. 2010. Research Methods on Language Learning an Introduction. 2nd ed. Malang: Universitas Negeri Malang (UM) Press.

Mart, Cagri Tugrul. 2013. "The Direct-Method: A Good Start to Teach Oral Language." International Journal of Academic Research in Business and Social Sciences 3 (11): 182. 
Naved, Zeeshan. 2016. "The Importance of the English Language in Today's World."

Oxford. 2013. The New Oxford Dictionary of English. United Kingdom: Oxford University Press.

Richards, Jack C, and Theodore S Rodgers. 2014. Approaches and Methods in Language Teaching. Cambridge university press.

Page | 18 Tom, Hutchinson, and Waters. 1987. English for Specific Purposes: A Learning Centered Approach. Imusselburgh: Scotprint Ltd.

Tomlinson, B. 2003. In Developing Materials for Language Teaching. London: YHT Itd.

Wardhaugh, Ronald. 2006. "Words and Culture." An Introduction to Sociolinguistics, 5th Ed, Blackwell Publishing, 221-41.

Weaver, Constance. 1996. Teaching Grammar in Context. ERIC.

Widodo, Handoyo. 2006. "Approaches and Procedures for Teaching Grammar." English Teaching 5 (1): 121.

Yule, George. 2016. The Study of Language. Cambridge university press. 